\title{
Development of a Morphology for the Description of Business Models for Technology Platforms
}

\author{
Günther Schuh ${ }^{1,2}$, Simon Ryschka ${ }^{1} \&$ Christian Kohns ${ }^{2}$ \\ ${ }^{1}$ Fraunhofer Institute for Production Technology IPT, Aachen, Germany \\ ${ }^{2}$ RWTH Aachen University, Aachen, Germany \\ Correspondence: Simon Ryschka, Fraunhofer Institute for Production Technology IPT, Steinbachstrasse 17, \\ 52074 Aachen, Germany. Tel: 49-241-8904-419. E-mail: simon.ryschka@ipt.fraunhofer.de
}

Received: October 9, 2014

Accepted: November 24, 2014

Online Published: April 27, 2015

doi:10.5539/emr.v4n1p49

URL: http://dx.doi.org/10.5539/emr.v4n1p49

\begin{abstract}
The importance of technology platforms as coherent networks of resources, capabilities and competencies is steadily increasing in technology-based companies. The reason is that technology platforms support companies to cope with one of today's most critical organizational complexity topics; that is, the balance between the conflicting priorities of fulfilling the increasing customer demand for individualized innovation while generating company-wide technological synergies. Thus, the business success of technology-based companies can be affected to a significant extent by the development of technology platforms and a consistent description of their business models. That means describing their structural design, in order to ensure technology platform-related, commercial opportunities. In practice however, the structural design of technology platforms is often poorly described and technology platform-related, commercial opportunities are not fully utilized. The reason is mainly due to the fact that there is no established opinion about a consistent framework, which supports the systematic derivation of the constitutional and configurable dimensions of a technology platform. Therefore, in this paper we develop a morphology that defines and characterizes the dimensions of technology platforms, in order to enable the description of business models in the context of technology platforms.
\end{abstract}

Keywords: technology management, strategic technology planning, business models, technology platforms

\section{Introduction}

The market environment of many technology-based companies can be characterized nowadays by a high extent of competition and a subsequent necessity to constantly introduce newly developed products into the global market place (Schuh et al., 2014). Shorter technology and product life cycles and therefore greater financial uncertainties with regard to the amortization of technological investments are the consequence (Ansoff, 1987; Wolfrum, 1994; Schuh et al., 2014). The external complexity is intensified by increasing market requirements for individualization and customized products (Rudolf, 2013). In order to address these complexity drivers and in order to ensure the corporate success in the long-term, technology-based companies are pressured to adjust their internal, organizational structures to the synergetic use and recombination of technologies (Schuh, 2011a). On the other hand individual solutions for different customer segments need to be generated as well (Rudolf, 2013). Thus, an increasing number of companies is organizing its technologies within technology platforms, which are spread over a wide range of intra-organizational business divisions and offer a uniquely perceived value by the customers (Jolly \& Nasiriyar, 2007). Therefore, the business success of technology-based companies can be affected to a significant extent by the development of technology platforms and a consistent description of their business models. Specially, that means describing their structural design, in order to ensure technology platform-related, commercial opportunities.

In practice many technology-based companies struggle with the description of the structural design of their technology platforms, which might lead to the loss of a technology platform's full commercial potential. The problem of an unsufficient description of the structural design often originates from the lack of consensus on how to systematically define the constitutional and configurable dimensions of a technology platform.

From the theoretical perspective, there is a lack of research with regard to the systematic description of the dimensions of technology platforms (Gawer, 2009; Gawer, 2014). This is surprising, due to the huge problems in 
the daily practice of technology-based companies and the negative economic impact of unsufficiently described technology platforms.

Therefore, in this paper we develop a morphology that defines and characterizes the dimensions of technology platforms, in order to enable the description of business models in the context of technology platforms. With the assistance of the morphology, technology-based companies will be able to identify the constitutional and configurable dimensions of technology platforms and thus will be able to manage the development of business models in the context of technology platforms. Additionally, we intend to develop a framework for future research in the academic field of technology platforms.

Section 2 of the paper gives an overview of the prevalent platform concepts and details their characteristics. Section 3 is going to make business models the subject of discussion as there will be a definition of business models and their dimensions in the context of this paper. Section 4 comprises a literature review of previous research concerning the systematical description of technology platforms. Based on the need for further research and the illustration of the applied methodology in section 5, the morphology for technology platforms is developed in section 6 . The conclusion in section 7 completes the paper.

\section{Platforms}

The following section is giving an overview of the prevalent platform concepts and determining their characteristics, in order to systematically detail the constitutional dimensions of technology platforms in section 6. At first, we will define the term platform for the purpose of this paper and introduce afterwards a definition of the term platform archtiecture, in order to describe the differences and similarities of different concepts within the prevalent platform landscape.

The platform term is frequently used for different purposes, e.g. in the product development, technology management, marketing or industrial economies (Baldwin \& Woodard, 2009). Hence, it is initially difficult to find an integrative definition (Sawhney, 1998). However, several similarities are existing, which can be observed in many different platform concepts. Sawhney (1998) presents a universal definition of the term platform to capture the fundamental logic behind the various concepts in academic research and practice. This paper adopts the author's definition, that a platform is "the process of identifying and exploiting the shared logic and structure in a firm's activities and offerings to achieve leveraged growth and variety" (Sawhney, 1998, p. 54).

\subsection{Platform Architecture}

An architecture is the abstract description of objects in a system and the relationships between these objects (Whitney, 2004). A platform architecture consists on the one hand of long-ranging core components, which only have a small amount of diversity, but therefore a large amount of reusability (Piezunka, 2011). On the other hand it consists of additional components (complements), which feature large diversity, little reusability and can be varied in the short-term (Baldwin \& Woodard, 2009).

Architectures, including platform architectures, can be characterized via the following subarchitectures, which are illustrated in Figure 1 (Baldwin \& Woodard, 2009; Piezunka, 2011):

- Physical architecture: Description of the reused core components and variation of the system's complemements (components can be either physical or non-physical)

- Technical architecture: Description of the platform's architectural control. Thus, the arrangement and connection between the core components and the variable complements of a platform, e.g. through standards and guidelines

- Functional architecture: Description of the platform activities and platform participants

- Dynamic operational architecture: Description of the platform output and the mechanisms of value generation 


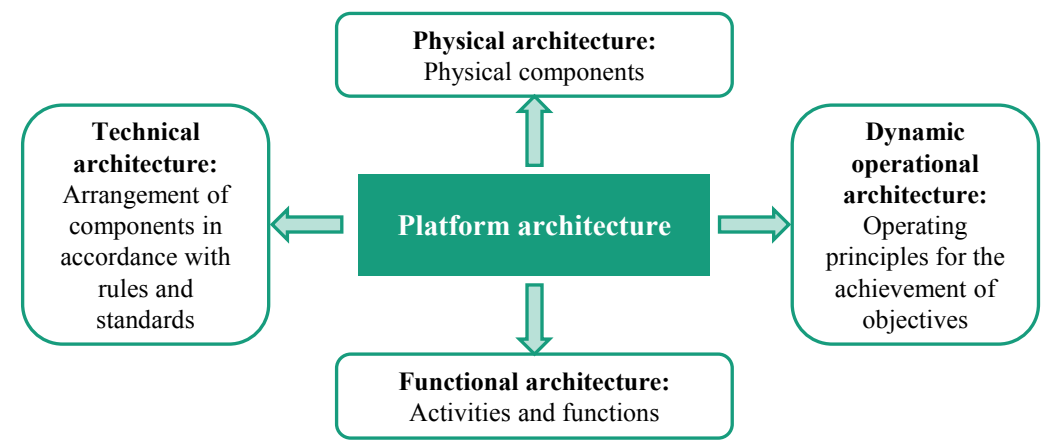

Figure 1. Characterization of platform architectures (Whitney, 2004)

\subsection{Platform Landscape}

For the purpose of the paper, a comprehensive overview of relevant platform concepts will be presented. The goal is to systematically compare these concepts and identify differences and similarities. Based on the comparison we will be able to detail the constitutional dimensions of technology platforms in section 6 . Figure 2 gives an overview of the analyzed platform landscape in this paper, which is however not entirely exhaustive. Furthermore, other platform concepts can be identified in the research literature, e.g. customer platforms or brand platforms (Sawhney, 1998; Gawer, 2009; Högmann, 2011). For reasons of clarity however, we focus in our paper on these eight platform concepts.
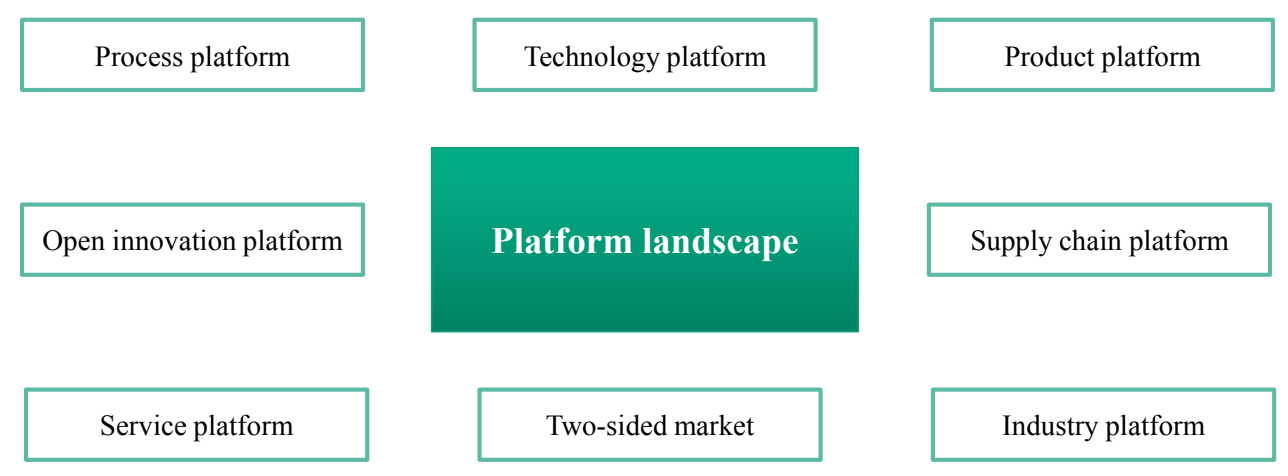

Figure 2. Overview of the analyzed platform concepts

Product platforms are a combination of components, which serve as the foundation for derivative products and determine a product family (Meyer \& Lehnerd, 1997; Rudolf, 2013). Additional components can be added, substituted or removed to differentiate the inidiviual products in a product family and thus be able to reach different market segments (Wheelwright, 1992; Rudolf, 2013). An example for a product platform is the Sony Walkman. Three fundamentally different models (miniature model, high audio quality, low-priced) each basing on an own product platform have been produced. The basis could be supplemented with additional components such as a radio or a remote control. Therefore, in total over 250 different models have been brought to market (Sanderson \& Uzumeri, 1995)

The concept of a supply chain platform extends the product platform by including the entire supply chain of a product (Gawer, 2009). A supply chain platform is a combination of sub-components and interfaces that define a combined structure. Based on this structure, derivative products can be efficiently produced by different partners of the supply chain (Gawer, 2009). Supply chain platforms can often be found in the automotive industry. Renault and Nissan, for example, formed an alliance and developed together a mutal supply chain platform for the Nissan Micra and the Renault Clio (Gawer, 2009).

Process platforms enable the coordination of product and process variety within the production by a holistic examination of the planning structures, thus facilitating an efficient and customized mass production (Jiao, 2007). The primary objective of a process platfform is the minimization of different process variations, originating from 
different product variations, based on the same product platform (Jiao, 2007). An example for a process platform is given by a fictional company producing customized vibration motors for cell phones. Due to differentiated customer requirements, the design and production of these motors possess a high degree of individualization, thus leading to a high product and process variety. The company addresses this challenge with a process platform that standardizes the coordination of product and process variety by implementing a detailed overall process structure within their production (Zhang, 2007).

Industry platforms are products, services or technologies developed by one or more companies that serve as a basis for complementary products, services or technologies, developed by complementary companies (Gawer, 2009). The operator of the platform therefore creates a multi-product-system in collaboration with the complementors, which is also referred to as a platform-based ecosystem (Piezunka, 2011; Gawer, 2009). Microsoft Windows as an operating system, for example, is the central component of a multi-product-system, which allows for the development of complementary software applications by providing central services with their operating system (Piezunka, 2011; Bresnahan, 2002).

Service platforms are defined as the synergetic combination of internet-based and physical services that are available for the consumer on demand. An example for a service platform is an application for taxicabs on smartphones, which enables the digital, personalized and location-dependant communication with the nearest available taxicab for the customer (Kagermann et al., 2014).

Two-sided markets are trading driven platforms, mostly virtually on a website, which enable the commercial transaction between different users (Gawer, 2009). An example for a two-sided market is the auction website eBay, which fulfills the purpose of an intermediary between buyers and sellers (Piezunka, 2011).

An open innovation platform is a virtual environment that enables the creation of innovations, based on a predefined task. The predefined task is executed by innovators, which interact time - and location-independent and regardless their institutional affiliation (Hall, 2013). An example for an open innovation platform is, Innocentive', a marketplace for innovation, where solutions for complex problems can be searched or offered (Möslein, 2011; Hall, 2013).

Table 1 is further detailing the platform concepts according to the defined dimensions of platform architectures.

Chart 1. Detailed comparison of the analyzed platform concepts (Piezunka, 2011; Gawer, 2009)

\begin{tabular}{|c|c|c|c|c|c|c|c|}
\hline & $\begin{array}{l}\text { Product } \\
\text { platform }\end{array}$ & $\begin{array}{l}\text { Supply chain } \\
\text { platform }\end{array}$ & $\begin{array}{l}\text { Industry } \\
\text { platform }\end{array}$ & $\begin{array}{l}\text { Process } \\
\text { platform }\end{array}$ & $\begin{array}{l}\text { Service } \\
\text { platform }\end{array}$ & $\begin{array}{l}\text { Two-sided } \\
\text { market }\end{array}$ & $\begin{array}{l}\text { Open innovation } \\
\text { platform }\end{array}$ \\
\hline 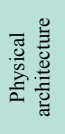 & $\begin{array}{l}\text { Core components and } \\
\text { complements }\end{array}$ & $\begin{array}{l}\text { Core components and } \\
\text { complements produced } \\
\text { by different partners } \\
\text { along the supply chain }\end{array}$ & $\begin{array}{l}\text { Platform operator } \\
\text { based multi-product- } \\
\text { system in } \\
\text { collaboration with } \\
\text { complementors }\end{array}$ & $\begin{array}{l}\text { Core processes and } \\
\text { variable sub-processes }\end{array}$ & $\begin{array}{l}\text { Technical } \\
\text { infrastructure and } \\
\text { additional services }\end{array}$ & $\begin{array}{l}\text { Virtual institution } \\
\text { with buyers, sellers } \\
\text { and transaction goods }\end{array}$ & $\begin{array}{l}\text { Virtual institution } \\
\text { with contributing } \\
\text { innovators }\end{array}$ \\
\hline 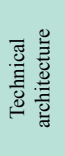 & $\begin{array}{l}\text { Standardized } \\
\text { interfaces between } \\
\text { core components and } \\
\text { complements }\end{array}$ & $\begin{array}{l}\text { Standardized interfaces } \\
\text { between core } \\
\text { components and } \\
\text { complements along the } \\
\text { supply chain }\end{array}$ & $\begin{array}{l}\text { Standardized } \\
\text { interfaces between } \\
\text { core components and } \\
\text { complements within } \\
\text { the platform-based } \\
\text { ecosystem }\end{array}$ & $\begin{array}{l}\text { Standardized process } \\
\text { interfaces }\end{array}$ & $\begin{array}{l}\text { Standardized } \\
\text { interfaces between } \\
\text { consumers and } \\
\text { companies }\end{array}$ & $\begin{array}{l}\text { Standardized } \\
\text { interfaces between } \\
\text { buyers and sellers } \\
\text { (transaction guideline) }\end{array}$ & $\begin{array}{l}\text { Predefined set of tasks } \\
\text { (work order) by the } \\
\text { platform organizer }\end{array}$ \\
\hline 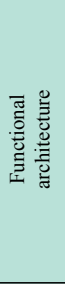 & $\begin{array}{l}\text { Participants: } \\
\text { - Platform operator } \\
\text { (single company) }\end{array}$ & $\begin{array}{l}\text { Activities: } \\
\text { - Production of a } \\
\text { product family } \\
\text { - Process coordination } \\
\text { along the supply } \\
\text { chain } \\
\text { Participants: } \\
\text { " Platform operator } \\
\text { (single or multiple } \\
\text { companies), supplier }\end{array}$ & $\begin{array}{l}\text { Activities: } \\
\text { - Ecosystem and } \\
\text { interface } \\
\text { coordination } \\
\\
\text { Participants: } \\
\text { - Platform operator } \\
\text { (single or multiple } \\
\text { companies), } \\
\text { complementors }\end{array}$ & $\begin{array}{l}\text { Activities: } \\
\text { " Coordination of } \\
\text { product and process } \\
\text { variety } \\
\\
\text { Participants: } \\
\text { - Platform operator } \\
\text { (single company) }\end{array}$ & $\begin{array}{l}\text { Activities: } \\
\text { " Initialization of a } \\
\text { collaborative } \\
\text { environment } \\
\\
\text { Participants: } \\
\text { - Platform operator } \\
\text { (single company), } \\
\text { consumers, service } \\
\text { companies }\end{array}$ & $\begin{array}{l}\text { Participants: } \\
\text { " Platform operator } \\
\text { (single company), } \\
\text { sellers, buyers }\end{array}$ & $\begin{array}{l}\text { Participants: } \\
\text { - Platform operator } \\
\text { (single company), } \\
\text { platform organizer, } \\
\text { innovators }\end{array}$ \\
\hline 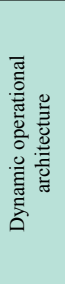 & $\begin{array}{l}\text { Output: } \\
\text { " Product family with } \\
\text { different product } \\
\text { variations } \\
\text { Generation of value: } \\
\text { " Economies of scale } \\
\text { and scope }\end{array}$ & $\begin{array}{l}\text { Output: } \\
\text { " Product family with } \\
\text { different product } \\
\text { variations } \\
\text { Generation of value: } \\
\text { " Economies of scale } \\
\text { and scope } \\
\text { " Reduction of } \\
\text { maintenance costs } \\
\text { along the supply } \\
\text { chain }\end{array}$ & $\begin{array}{l}\text { Output: } \\
\text { " Platform-based } \\
\text { ecosystem } \\
\\
\text { Generation of value: } \\
\text { " Innovative problem } \\
\text { solutions (products, } \\
\text { services and } \\
\text { technologies) }\end{array}$ & $\begin{array}{l}\text { Output: } \\
\text { - Definition of } \\
\text { relevant process } \\
\text { variations } \\
\text { Generation of value: } \\
\text { = Minimization of } \\
\text { process variations }\end{array}$ & $\begin{array}{l}\text { Output: } \\
\text { " Individual, digital } \\
\text { and physical } \\
\text { services variations } \\
\text { Generation of value: } \\
\text { " Combination of } \\
\text { digital and physical } \\
\text { services }\end{array}$ & $\begin{array}{l}\text { Output: } \\
\text { " Initiation of } \\
\text { transactions } \\
\\
\text { Generation of value: } \\
\text { " Reduction of } \\
\text { search costs and } \\
\text { transaction costs }\end{array}$ & $\begin{array}{l}\text { Output: } \\
\text { " Ideas, drafts, } \\
\text { concepts, } \\
\text { prototypes } \\
\text { Generation of value: } \\
\text { " Innovative problem } \\
\text { solutions (products, } \\
\text { services and } \\
\text { technologies) }\end{array}$ \\
\hline
\end{tabular}




\subsection{Technology Platforms}

The term technology platform is used inconsistently in academia and in practice (Jolly \& Nasiriyar, 2007). Thus, it is mandatory to determine a precise definition for the purpose of the paper. Technology platforms hereafter will be defined as coherent networks of resources, capabilities and competencies within technology-based companies (Breuer, 2006). An extension of such a technology platform understanding in technology-based companies is represented by integrated technology platforms (Högmann, 2011).

Technology platforms in technology-based companies represent an interconnected part of a company's knowledge base as coherent networks of resources, capabilities and competencies (Rosier, 2006; Breuer, 2006). A technology platform is based on unique, technological knowledge that spreads over a wide range of intra-organizational business divisions and exploits a maximised field of application (Jolly \& Nasiriyar, 2007). A flexible adjustement to changing environmental and competitive circumstances is ensured through a dynamic reconfiguration process of technologies and competencies within a technology platform (Stig, 2013; Shapiro, 2006).

Figure 3 illustrates an exemplary technology platform on the subject of lightweight design (Schuh et al., 2014).

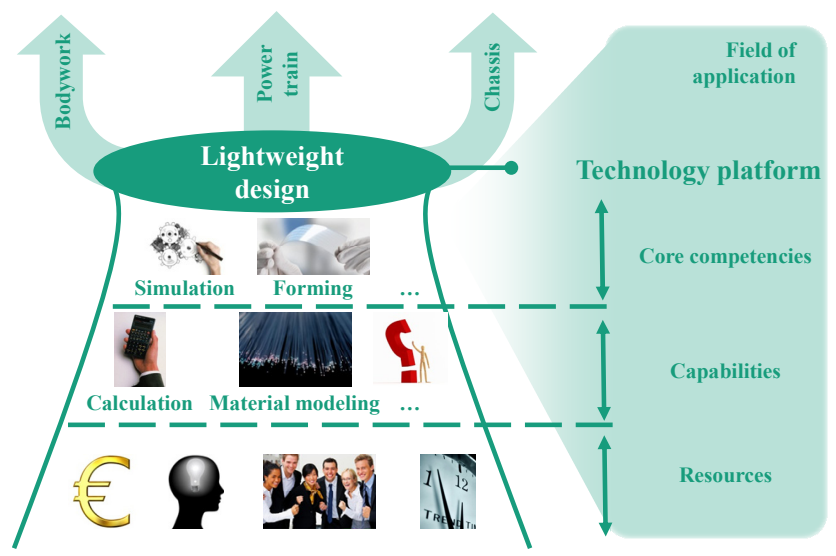

Figure 3. Illustrative excerpt of a technology platform on the subject of lightweight design (Schuh et al., 2014)

The core competency simulation of lightweight components for example is based on the capabilities of databased material modeling and the mathematical calculation of specific algorithms for the lightweight components. The core competency is founded on longstanding collaborations with leading companies and universities in the field of simulation technologies for lightweight components. The illustrated technology-based company transformed the core competencies of their technology platform lightweight design successively into products of their business divisions bodywork, power train and chassis (Schuh et al., 2014).

The integrated technology platform approach represents the consolidation of several platform concepts: an integrated technology, process and product platform (Högmann, 2011). The platforms interact with each other and comprise valuable resources that are exploited in multiple applications. The main challenge within the integrated technology platform concept is the effective interconnection of the different level of technology, product and production (Levandowski, 2013).

\section{Business Models}

In the following section we will introduce a definition of the term business model in the context of the paper and derive business model specific dimensions, which will function as a consistent framework for the configurable dimensions of technology platforms in section 6 .

The concept of business models is still without a commonly accepted definition (Chesbrough \& Rosenbloom, 2002; Zott et al., 2011). GEORGE \& BOCK present a practical definition of the business model concept to converge the fragmented literature. This paper adopts the authors' definition that a business model is "the design of organizational structure to enact a commercial opportunity" (George \& Bock, 2011, p. 99). The organizational structure can be divided, as illustrated in figure 4, into the following three dimensions: resource structure, transactive structure and value structure (George \& Bock, 2011). 


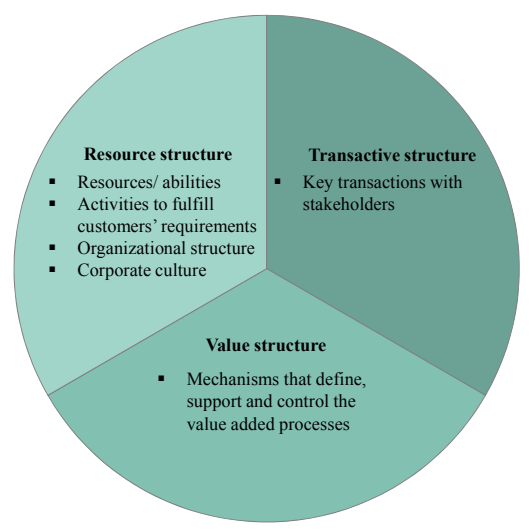

Figure 4. Dimensions of a business model (George \& Bock, 2011)

The resource structure refers to the static architecture of a company's organization. This includes the configuration of the resources, abilities and activities that are utilized, in order to fulfill the customers' requirements. Furthermore, implicit aspects of a company's organizational structure such as the corporate culture are considered as well (George \& Bock, 2011).

The transactive structure is the organizational configuration that describes the key transactions with a company's stakeholders, e.g. shareholders and employees. The transaction elements of a business model determine a structure that is directly associated with a company's added value (George \& Bock, 2011).

Finally the value structure represents the mechanisms that define, support and control the added value processes. The value structure functions as an intermediary between a commercial opportunity and its exploitation by the elements of the resource and transactive structure (George \& Bock, 2011).

The individual definition of the three business modell dimensions determines a systematic framework and hence allows for a logical and coherent description of business models (Demil \& Lecocq, 2011). The framework will be utilised in section 6 , in order to detail the configurable dimensions of technology platforms.

\section{Literature Review}

The following section comprises the review of seven exemplary research papers, which illustrate different configurable aspects of technology platforms.

Böhlke et al. discuss different configurable aspects of technology platforms by illustrating examples from technology-based companies in the industrial practice. The authors define the specification of the platform integration into the organizational structures, the way of transferring knowledge, the determination of the optimal form of cooperation with external partners and the selection of possible internal stakeholders as relevant, configurable aspects of a technology platform (Böhlke et al., 2005). However, in their paper the authors do not intend to establish a cohesive framework that systematically structures the technology platform dimensions in a logical order.

Breuer discusses stakeholder groups of a technology platform that can be found on the one hand within a company and on the other hand outside a company e.g. customers or markets (Breuer, 2006). The author defines the research and development department as an internal stakeholder group of technology platforms. Even though the work of BREUER provides several indicators for different technology platform stakeholders, there is not a systematic overview on the possible stakeholders of a technology platform.

Shapiro describes how different technologies within a technology platform can be combined to form new products as well as entire new product lines. As the author illustrates, a good example for such development of new products from technology platforms (e.g. vapour processing or adhesives) is the company 3M (Shapiro, 2006). However, the author does not detail the 'working principles' behind these technology platforms with regard to their value structure, resource structure or transactive structure.

Jolly and Nasiriyar focus in their paper on different, technology management related activities of technology platforms. On the one hand, they attribute a high significance to the systematic planning of technology developments for technology platforms. On the other hand, the authors determine the exploitation of technological resources as a central activity of technology platforms, in order to advance to new fields of 
application and diversify the existing product portfolio (Jolly \& Nasiriyar, 2007). In total, the authors describe several, isolated platform activities without putting them into the context of a connected technology management process.

Levandovski et al. discuss the importance of a close interaction between the production system and the technology platforms in producing companies. They use the example of an engine supplier in the aerospace industry (Lev et al., 2013). However the authors describe only a single case study and focus solely on the interaction of relevant stakeholders in the production of aerospace engines with technology platforms.

Stig discusses in detail several methods of internal knowledge documentation within technology platforms. The author defines three levels of the internal knowledge documentation, describing the technological base of technology platforms from different perspectives. A technology portfolio supports an initial structuring of a platform's technology base and describes a company's technological abilities from a strategic perspective. Technology catalogs provide a more detailed insight into the technology base of technology platforms by offering links to relevant basic information. Finally, technology toolboxes provide extensive technology reports including links to relevant internal experts and visualize the application of specific technologies of a technology platform withtin the current product portfolio (Stig, 2013). Even though the author gives a comprehensive overview of a technology platform's documentation methods, he lacks to put his findings into an overarching framework that supports the systematic derivation of platform dimensions.

Andereggen et al. develop in the context of universities a concept for the central management and the shared use of strategically important research equipment at the ETH Zurich (Andereggen et al., 2013). Their approach at the ETH Zurich adresses the increasing acquisition and maintenance costs of capital-intensive research equipment through shared use, crossing traditional faculty boarders (Blaser, 2012). The authors describe in a structured manner different configurable dimensions of their technology platforms. However these dimensions can not be applied directly to the understanding of technology platforms in the context of the paper due to their university application background.

Summarizing, seven exemplary research papers has been analyzed, demonstrating individual aspects of technology platforms. However, the illustrated research approaches lack a comprehensive and consistent framework, which supports the systematic derivation of technology platform dimensions. The purpose of this paper is to address this need for research and to display a cohesive morphology that defines and characterizes the dimensions of technology platforms, in order to enable the description of business models in the context of technology platforms.

\section{Methodology}

In this section we develop the conceptual framework of the morphology and determine the constitutional and configurable dimensions of technology platforms for the further detailing in section 6. Based on this approach, we ensure the structured achievement of the research objective of this paper, which is the description of business models for technology platforms.

From a theoretical perspective, a morphology serves as a systematic classification of a study object by introducing logical criterias, which are adapted to a study's specific objectives (Welter, 2006). The most important methodology of the morphological research is the construction and analysis of the morphological box that is applied in this paper (Zwicky, 1989).

In order to achieve the paper's research objective we introduce the physical, technical, functional and dynamic operational platform architectures as the constitutional dimensions of the morphology. In such a manner we are able to generate a systematic illustration of the differences between a technology platform and the other platform concepts. As illustrated in figure 5, on the other hand we introduce the resource, transactive and value structure of a business model as the configurable dimensions of the morphology. In this way, we are able to systematically detail the specific, configurable dimensions of technology platforms in section 6 . 


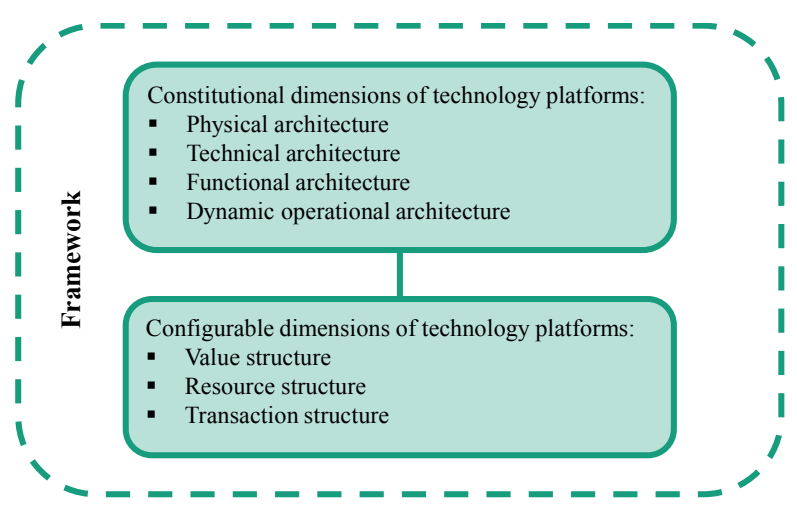

Figure 5. Conceptual framework of the morphology for technology platforms (Schmitz-Urban, 2013)

Overall, the framework that is presented in figure 5 is providing a systematization for the development of the morphology in section 6 .

\section{Morphology Development}

In this section, we are detailing the morphology, in order to describe business models for technology platforms. The detailing is conducted based on the conceptual framework, which is introduced in section 5. At first, we will detail the constitutional dimensions of a technology platform and generate for each dimension several sub-dimensions and attributes. By doing so, we will be able to present the fundamental differences between technology platforms and other platform concepts. Afterwards, the configurable dimensions of a technology platform will be detailed as well, generating sub-dimensions and attributes based on the dimensions of a business model. As a consequence, technology-based companies will be able to manage the development of business models in the context of their specific technology platforms.

\subsection{Constitutional Dimensions of Technology Platforms}

The physical architecture of a technology platform consists of a coherent network of resources, capablities and competencies (Rosier, 2006). In this context, core competencies play a central role by correlating to the complex problem solving processes of companies and therefore fundamentally influencing their competitiveness (Koruna, 1999). They not only cause an increase in effectivity and efficiency, but also are rare, hardly imitable and thus not substitutable (Müller-Stewens, 2001). Hence, the core competencies are the core components of a technology platform's physical architecture. The lower levels within the coherent network (resources, capabilities and competencies) are the variable components of a technology platform's physical architecture. Variation can be achieved via integration or disintegration of resources, capabilities and competencies (Jolly \& Nasiriyar, 2007).

Based on the discussion of the other platform concepts in section 2, the further attributes "core components and complements", "core processes and sub-processes", "technical infrastructure and variable services" as well as the "virtual institution with variable contributors" have been identified. The following figure 6 is giving an overall overview of these attributes of the physical architecture and indicating the constitutional attribute of technology platforms "core competencies and resources, capabilities, technologies".
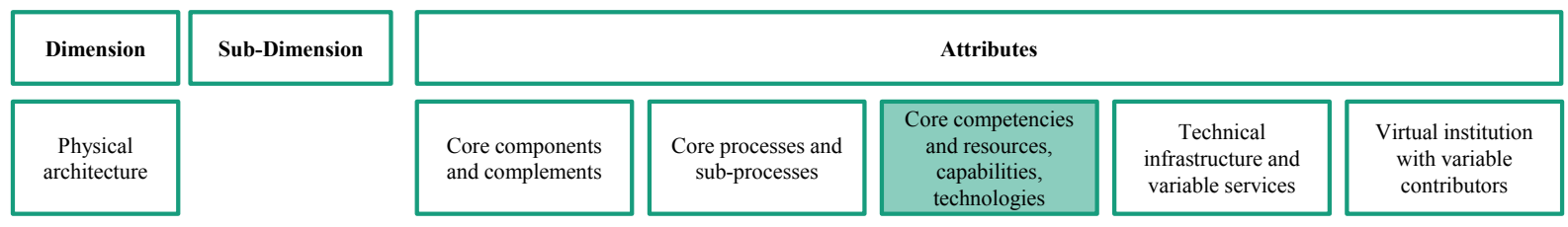

Figure 6. Physical architecture of technology platforms

The technical architecture details the mechanisms that can be used to control the platform architecture, thus the arrangement and connection between the core components and the variable complements of a platform (Whitney, 2004). In case of technology platforms it can be distinguished between the following three processes, which define the technical architecture: resource combination, working methods, organizational routines (Rosier, 2006). 
The resource combination bundles different material and immaterial resources into capabilities. Subsequently, capabilities are integrated into working methods and result in applicable technologies. Working methods that establish themselves within a company eventually develop into standardized processes. Finally, organizational routines bundle different technologies into a range of efforts, which are necessary for the creation of core competencies (Rosier, 2006). As illustrated in figure 7, technology platforms differ from the other platform concepts with regard to their technical architecture due to the constitutional attribute "resource combinations, working methods and organizational routines". Additionally, the discussion of the other platform concepts in section 2 revealed that the architectural control can also be enforced via mechanisms such as "standardized interfaces" and "work orders".
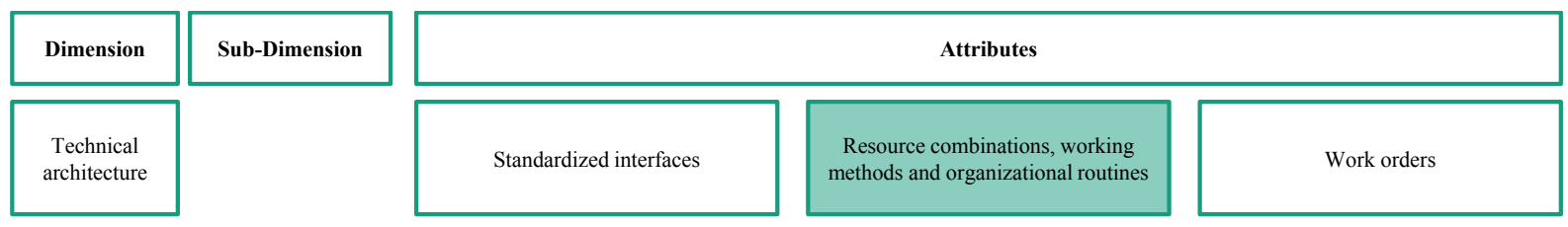

Figure 7. Technical architecture of technology platforms

The functional architecture describes the platform activities and the platform participants (Whitney, 2004). In the particular case of technology platforms it is the the goal to systematically ensure technological uniqueness by conducting activities of the technology management (Böhlke et al., 2005; Klappert, 2011).

Participants of technology platforms are both the company that operates the platform and further participants, like external partnes, which provide parts of the coherent network of resources, capabilities and competencies. In case of high costs and increased complexity issues concerning the internal development of a technology platform's coherent network, a technology-based company possibly decides to outsource parts of the coherent network, which are necessary for the formation of core competencies and technological uniqueness (Eisenmann, 2007; Jolly \& Nasiriyar, 2007; Breuer, 2006). Therefore, technology platforms are constituted by technology management activities that are conducted by the platform operator as well as further participants. As illustrated in figure 8, the platform activities "production", "coordination", "intermediation" and "initialization" as well as the participant "platform organizer" have been developed in the literature analyzis of section 2 for the other platform concepts.
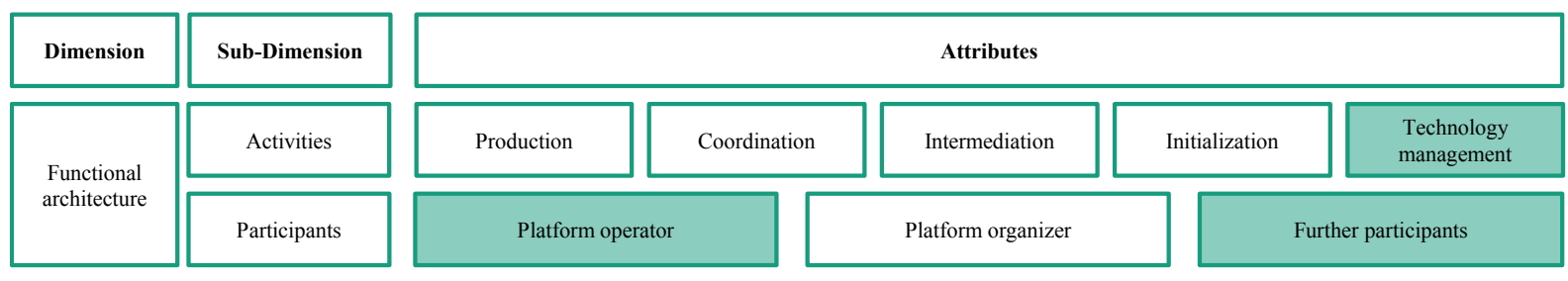

Figure 8. Functional architecture of technology platforms

In the dimension dynamic operational architecture it can be distinguished between the platform output and the generation of value within platforms (Whitney, 2004). The platform output describes the results of the platform activities that lead to additional value for the company. The sub-dimension value generation discloses the underlying mechanisms of a platform's creation of value.

The output of a technology platform's dynamic operational architecture can be described as the synergetic renewal, rejuvenation and restructuration of technological resources, which are integrated within the coherent platform network (Jolly \& Nasiriyar, 2007). The value generation of the synergetic collaboration of the technological resources is a unique technological knowledge, which enables a unique technological performance (Rosier, 2006). As displayed in figure 9, technology platforms are constituted in comparison to the other platform concepts, which have been analyzed in section 2, by technological uniqueness in their outputs and economies of scope in their generation of value. 


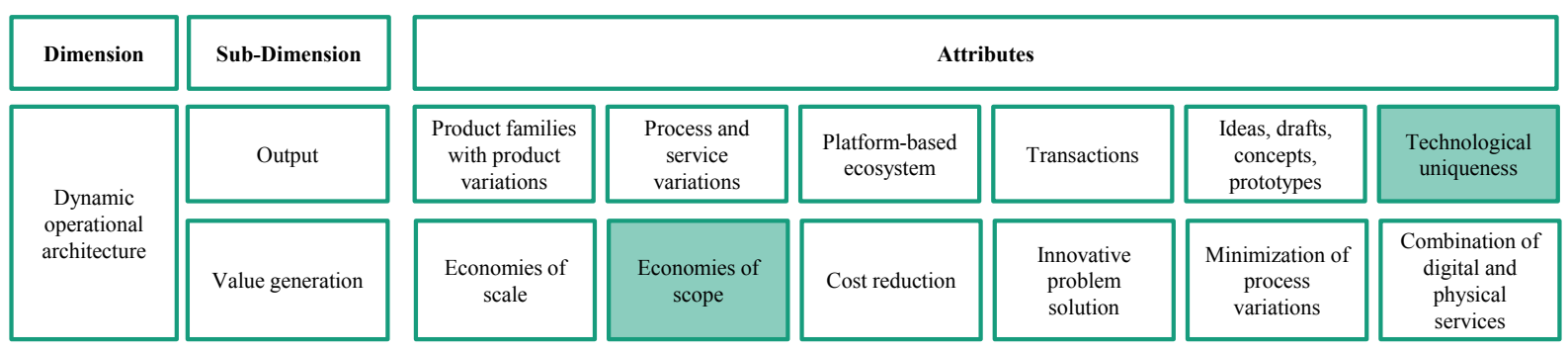

Figure 9. Dynamic operational architecture of technology platforms

\subsection{Configurable Dimensions of Technology Platforms}

The configurable aspects of the technology platform morphology will be detailed according to the three dimensions of a business model: value structure, resource structure and transactive structure. The configurable sub-dimensions activities and financing are formulated for the value structure of a technology platform. Furthermore, the sub-dimensions material and immaterial resources as well as the organizational implementation are formulated for the resource structure of a technology platform. The transactive structure of a technology platform consists of the sub-dimensions knowledge documentation and stakeholders.

The activities of a technology platform comprise the cross-functional activities of the technology management (Binder \& Kantowsky, 1996; Klappert, 2011). The platform specific focus of the technology management activities plays a decisive role for the overall design, control and development of a technology platform's achievement of technological uniqueness (Böhlke et al., 2005). It can be differentiated between technology intelligence, technology planning, technology development, technology exploitation, technology protection and technology assessment as the activities of a technology platform (Schuh et al., 2011b).

Another aspect of the value structure is the financing of technology platforms. A possible form of financing is the corporate budget, which is generated on the overall company hierarchy. As a consequence, the technology platform can operate more detached from the individual interests of the business divisions (Breuer, 2006; Specht, et al., 2002). Contrary, another form of financing can be established by a common budget of those business divisions, which are participating within the technology platform and provide their own internal resources. Thus, the interests and needs of the involved business divisons are satisfied through such a financing attribute (Rosier, 2006). Another possibility of financing a technology platform is determined by a project budget, which is contributed by the individual business divisions as well. However, these business divisions don't finance permanently, but rather temporary and very specific to certain technology management activities (Breuer, 2006; Specht et al., 2002). Figure 10 summarizes the platform activities and financing options of a technology platform.
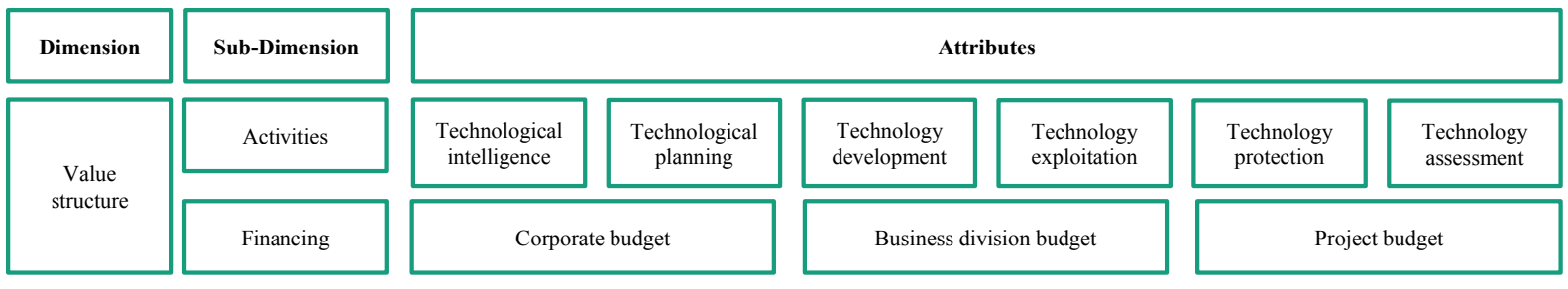

Figure 10. Value structure of technology platforms

The development and maintenance of technology platforms requires sufficient capacities in terms of different material and immaterial resources (Böhlke et al., 2005; Müller-Stewens, 2001). A technology platform's material resources comprise financial resources, e.g. equity and debt capital, physical resources, e.g. raw material, machinery and buildings as well as IT-based resources, e.g. software or hardware (Müller-Stewens, 2001). Regarding the immaterial resources of technology platforms it can be differentiated between inventory resources, e.g. patents and human resources, e.g. specific platform staff such as platform managers. 
Furthermore, different alternatives for the organizational implementation of technology platforms can be determined: real or virtual, central or decentralized, temporary or permanent (Böhlke et al., 2005). A technology platform, which is implemented as a real organizational feature consists of permanent workplaces for the platform specific staff implemented in the company. Contrary, the virtual implementation of a technology platform is characterized by modern information and communication tools, which are used across different business divisions to coordinate the platform activities (Müller-Stewens, 2001). The options "central" and "decentralized" implementations refer to the location of the technology platform within the organizational structure. Centrally implemented technology platforms can function at a higher level as service provider for several business divisions (Rosier, 2006). A decentralized implemented technology platform is significantly dominated by a specific business division that coordinates the activities of the technology platform and provides the majority of resources. Different other business divisions that are interested in such a technology platform bring their expertise in the form of resources and benefit from the cooperation (Böhlke et al., 2005). A permanent implementation of a technology platform is characterized by platform specific activities that are a constant part of the day-to-day business of the involved platform staff. An alternative is the temporary implemented technology platform that can be installed in case of larger development projects and closed down after the finalization of the project (Böhlke et al., 2005). Figure 11 summarizes the outcomes for the resource structure of technology platforms.

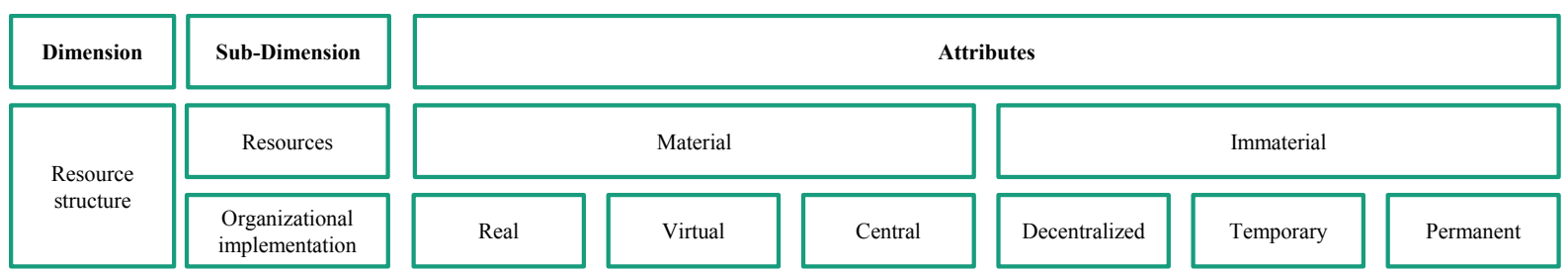

Figure 11. Resource structure of technology platforms

The knowledge documentation within technology platforms can be conducted in several different ways. Face-to-face communication is ensuring an infomal documentation of knowldge without special facilities (Campbell, 1997). Furthermore, technology platforms can offer regular workshops for specific topics, in order to ensure a controlled documentation of knowledge (Stig, 2013). A technology portfolio supports an initial structuring of a platform's technology base and describes a company's technological capabilities from a strategic perspective (Stig, 2013). Technology catalogs provide a more detailed insight into the technology base of technology platforms by offering links to relevant basic information (Stig, 2013). Especially within widely diversified companies, technology catalogs in the form of IT-tools are commonly used, in order to offer a possibility for the employees to share their technology related knowledge with colleagues in other parts of the world. Finally, technology toolboxes provide extensive technology reports including links to relevant internal experts and visualize the application of specific technologies of a technology platform withtin the current product portfolio (Stig, 2013).

Technology platforms address different internal stakeholders that take advantage from the platform activities. Possible stakeholders are organizational units that make a high contribution to the added value, namely the procurement, the research and development, the production and the marketing of a technology-based company (Schreyögg, 2008). Through technology platforms, the procurement can receive a clear orientation regarding the acquisition of technologies and can avoid uneconomical, technological acquisitions (Böhlke et al., 2005). Also, technology platforms can be implemented as a prominent aspect of the communication with customers and act as an own brand, with regard to the marketing activities of a company (Böhlke et al., 2005). The research and development as well as the production department can be defined as the core stakeholders of a technology platform. They benefit from a technology platform's synergetic value generation during the development of (production) technologies and their ability for problem-solvings in production-technical questions, due to a contiuous knowledge further development (Rosier, 2006; Böhlke et al., 2005). Figure 12 summarizes the outcomes for the transactive structure of technology platforms. 


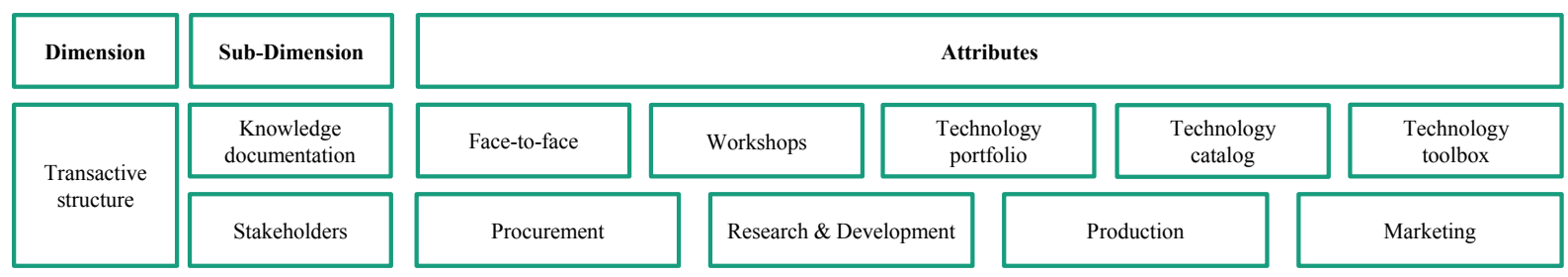

Figure 12. Transactive structure of technology platforms

\section{Conclusion and Further Research}

In this paper we developed a framework, in order to systematically derive the morphology dimensions of a technology platform's business model. In total four constituational dimensions with four sub-dimensions have been formulated, which specify the differences between a technology platform and other platform concepts. Additionally, we defined three configurable dimensions with six sub-dimensions, which serve as an orientation for technology-based companies that intend to systematically manage the business models of their technology platforms. Figure 13 gives a summarizing overview of this paper's outcome.

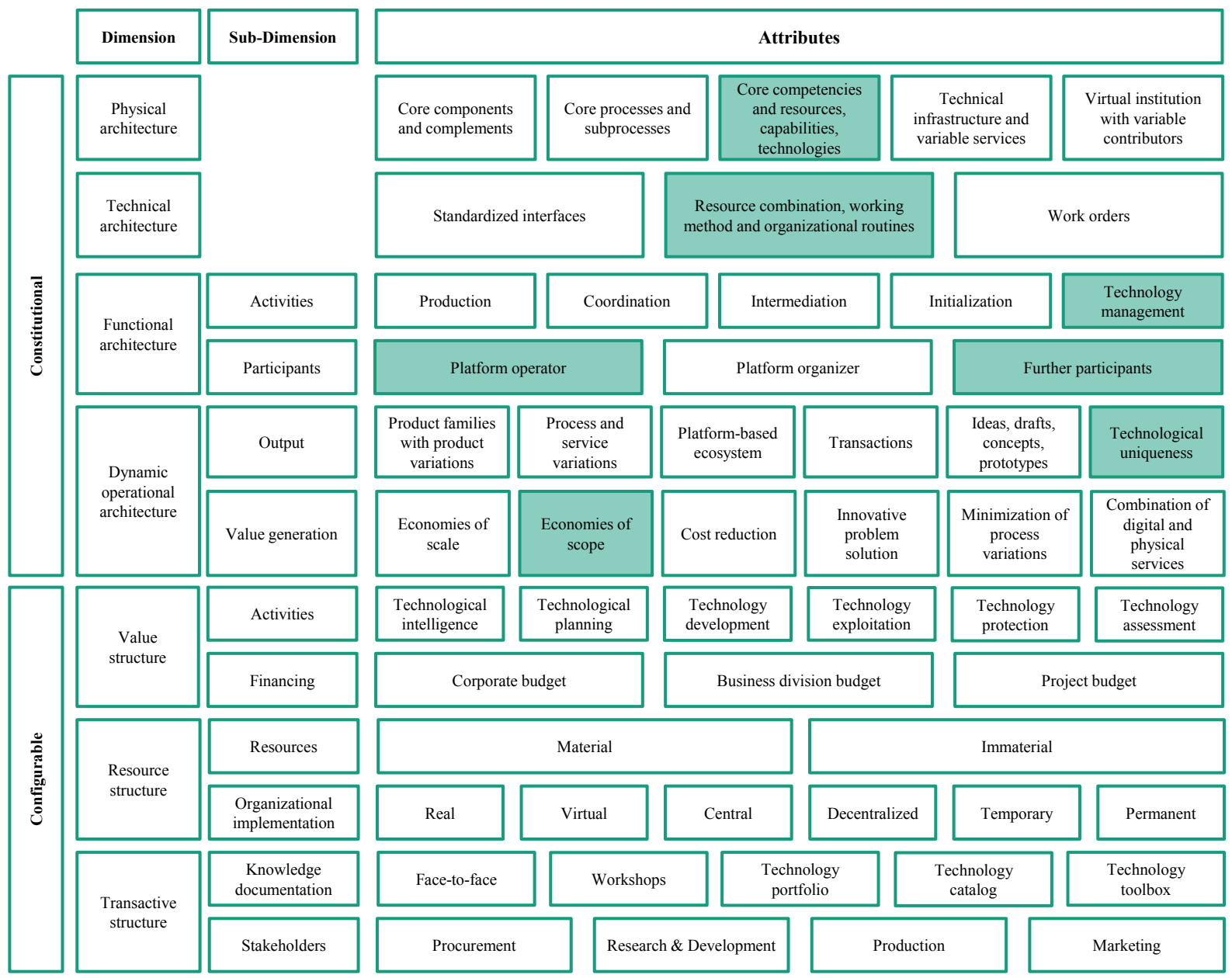

Figure 13. Morphology for the description of a technology platform's business model

The outcomes of this research paper emphasize the importance to systematically describe the business models of technology platforms. Specific dimensions, sub-dimensions and attributes are delivered to those represents who are responsible for long-term, strategic issues and are describing business models of technology platforms within technology-based companies. 
Further research is needed to expand and validate the derived morphology. Especially, empirical studies should be carried out to consistently validate the proposed morphology. Such an investigation would further promote a systemtically description of business models for technology platforms.

\section{References}

Andereggen, S., Zoller, F. A., \& Boutellier, R. (2013). Sharing Research Equipment to Bridge Intraorganizational Boundaries. Research Technology Management, 56(1), 49-57. http://dx.doi.org/10.5437/08956308X 5601082

Ansoff, H. I. (1987). Strategic Management of Technology. Journal of Business Strategy, 7, 28-39. http://dx.doi.org/10.1108/eb039162

Baldwin, C. Y., \& Woodard, C. J. (2009). The architecture of platforms: a unified view. In A. Gawer (Ed.), Platforms, markets and innovation (1st ed., pp. 19-44). Cheltenham, UK: Edward Elgar Publishing. http://dx.doi.org/10.4337/9781849803311.00008

Binder, V., \& Kantowsky, J. (1996). Technologiepotentiale. Neuausrichtung der Gestaltungsfelder des Strategischen Technologiemanagements. Wiesbaden: Deutscher Universitäts-Verlag. http://dx.doi.org/10.1007/978-3-663-09032-8

Blaser, C, Andereggen, S., \& Boutellier, R. (2012). Zentrale Technologieplattformen: Zwischen Forschung und Services. Wissenschaftsmanagement, 5, 38-43.

Böhlke, U. H., Breuer, T., Dahlmann, P., Demarmels, A., Koglin, K., Pelzer, ... Spohr, G. U. (2005). Technologieplattformen managen-Ein essentieller Beitrag zur Umsetzung der Unternehmensstrategie. In Aachener Werkzeugmaschinenkolloqium (pp. 393-415).

Bresnahan, T. F. (2002). The economics of the Microsoft case. Stanford University Working Paper, 232. Retrieved from http://papers.ssrn.com/sol3/papers.cfm?abstract_id=304701 http://dx.doi.org/10.2139/ssrn.304701

Breuer, T. (2006). Management von Technologieplattformen in diversifizierten Unternehmen (1st ed.). Aachen: Shaker.

Campbell, A., \& Goold, M. (1997). Building core skills. In A. Campbell, \& K. Sommer-Luchs (Eds.), Core competency-based strategy. London: Thomson Business Press.

Chesbrough, H., \& Rosenbloom, R. S. (2002). The role of the business model in capturing value from innovation: Evidence from Xerox Corporation's technology spin-off companies. Industrial \& Corporate Change, 11, 529-555. http://dx.doi.org/10.1093/icc/11.3.529

Demil, B., \& Lecocq, X. (2010). Business model evolution: In search of dynamic consistency. Long Range Planning, 43(2/3), 227-246. http://dx.doi.org/10.1016/j.lrp.2010.02.004

Eisenmann, T. (2007). Managing proprietary and shared platforms: A life-cycle view. Carleton University Working Paper, 07-105. Retrieved from http://www.sce.carleton.ca/faculty/tanev/TTMG_5100/ Session\%2012\%20-\%20Technological\%20platforms\%20and\%20standards/Eisenmann_Managing_propriet ary_and_shared_platforms_07_105.pdf

Gawer, A. (2009). Platform dynamics and strategies: From products to services, In A. Gawer (Ed.), Platforms, marktes and innovation. (1st ed., pp. 45-76). Cheltenham, UK: Edward Elgar Publishing. http://dx.doi.org/10.4337/9781849803311.00009

Gawer, A. (2014). Bridging differing perspectives on technological plattforms: Toward an integrative framework. Research Policy, 43, 1239-1246. http://dx.doi.org/10.1016/j.respol.2014.03.006

Hallerstede, S. H. (2013). Managing the lifecycle of Open Innovation Platforms. Wiesbaden: Springer. http://dx.doi.org/10.1007/978-3-658-02508-3

Högman, U. (2011). Processes and platforms Aligned with technology development-The perspective of a supplier in the aerospace industry (Doctoral dissertation).

Jiao, J., Simpson, T. W., \& Siddique, Z. (2007). Product family design and platform-based product development: A state-of-the-art review. Journal of Intelligent Manufacturing, 18, 5-29. http://dx.doi.org/10.1007/s10845-007-0003-2

Jolly, D. R., \& Nasiriyar, M. (2007, May 13-17). Technology Platform Exploitation: Definition and Research Boundaries. Paper presented at the 16th International Conference on Management of Technology (IAMOT) 
(pp. 1-32). USA: Miami.

Kagermann, H., Riemensperger, F., Hoke, D., Helbig, J., Stocksmeier, D., Wahlster, W., ... Schweer, D. (2014). Smart Service Welt Recommendations for the strategic initiative Web-based services for businesses. Berlin: Acatech - National Academy of Science and Engineering.

Klappert, S., Schuh, G., \& Aghassi, S. (2011). Einleitung und Abgrenzung. In G. Schuh, \& S. Klappert (Eds.), Technologiemanagement. Handbuch Produktion und Management 2 (2nd ed., pp. 5-10). Berlin: Springer. http://dx.doi.org/10.1007/978-3-642-12530-0_2

Koruna, S. (1999). Kernkompetenzen-Dynamik: Überleben im Hyperwettbewerb mit strategischen Allianzen. Zürich: Industrielle Organisation.

Levandowski, C. E., Corin-Stig, D., Bergsjö, D., Forslund, A., Högman, U., Söderberg, R., \& Johannesson, H. (2013). An integrated approach to technology platform and product platform development. Concurrent Engineering, 21, 65-83. http://dx.doi.org/10.1177/1063293X12467808

Meyer, M. H., \& Lehnerd, A. P. (1997). The power of product platforms (1st ed.). New York, USA: The Free Press.

Möslein, K. M., \& Neyer, A. (2011). Open Innovation, Grundlagen, Herausforderungen, Spannungsfelder. In A. Zerfaß, \& K. M. Möslein (Eds.), Kommunikation als Erfolgsfaktor im Innovationsmanagement (1st ed., pp. 85-103). Wiesbaden: Gabler.

Müller-Stewens, G., \& Lechner, C. (2001). Strategisches Management: Wie strategische Initiativen zum Wandel führen. Stuttgart: Schäffer-Poeschel.

Piezunka, H. (2011). Technological platforms. Journal für Betriebswirtschaft, 61(2-3), 179-226. http://dx.doi.org/10.1007/s11301-011-0078-x

Rodermann, M. (1999). Strategisches Synergiemanagement (1st ed.). Wiesbaden: Gabler.

Rosier, C. (2006). Zentrale Technologieentwicklung in diversifizierten Unternehmen (1st ed.). Aachen: Shaker.

Rudolf, S. (2013). Produktionsgerechte Baukastengestaltung (1st ed.). Aachen: Apprimus.

Sanderson, S., \& Uzumeri, M. (1995). Managing product families: The case of the Sony Walkman. Research Policy, 24(5), 761-782. http://dx.doi.org/10.1016/0048-7333(94)00797-B

Sawhney, M. S. (1998). Leveraged high-variety strategies: From portfolio thinking to platform thinking. Journal of the Academy of Marketing Science, 26, 54-61. http://dx.doi.org/10.1177/0092070398261006

Schuh, G., Drescher, T., Beckermann, S., \& Schmelter, K. (2011a). Technologieverwertung. In G. Schuh, \& S. Klappert (Eds.), Technologiemanagement: Handbuch Produktion und Management 2 (2nd ed., pp. 241-282). Berlin: Springer. http://dx.doi.org/10.1007/978-3-642-12530-0_9

Schuh, G., Klappert, \& S., Moll, T. (2011b) Ordnungsrahmen Technologiemanagement. In G. Schuh, \& S. Klappert (Eds.), Technologiemanagement. Handbuch Produktion und Management 2 (2nd ed., pp. 11-31). Berlin: Springer. http://dx.doi.org/10.1007/978-3-642-12530-0_3

Schuh, G., Guo, D., Wölk, S., Ryschka, S., Schön, N., \& Wemhöner, H. (2014, September). Strategische Technologieplanung: Von der Strategie über die Roadmap zur Plattformentwicklung. IM+io Das Magazin für Innovation, Organisation und Management, 56-65.

Shapiro, A. R. (2006). Measuring innovation: Beyond revenue from new products, Research-Technology Management, 49(6), 42-51.

Schmitz-Urban, A. P. (2013). Entwicklung einer Morphologie für Business-Communities (1st ed.). Aachen: Apprimus.

Schreyögg, G. (2008). Organisation, Grundlagen moderner Organisations gestaltung (5th ed.). Wiesbaden: Gabler.

Specht, G., Beckmann, C., \& Amelingmeyer, J. (2002). F \& E-Management, Kompetenz im Innovations management (Vol 2, 2nd ed.). Stuttgart: Schäffer-Poeschel.

Stig, D. C. (2013). A proposed technology platform framework to support technology reuse. Proceedings of the Conference on Systems Engineering Research (CSER) (pp. 918-926). http://dx.doi.org/10.1016/j.procs.2013.01.096

Welter, M. (2006). Die Forschungsmethode der Typisierung. Wirtschaftswissenschaftliches Studium, 35(2), 
113-116. http://dx.doi.org/10.15358/0340-1650-2006-2-113

Wheelwright, S. C., \& Clark, K. B. (1992). Creating project plans to focus product development. Harvard Business Review, 70(2), 67-83.

Whitney, D. Crawley, E., de Weck, O., Eppinger, S. Megee, C. Moses, J., ... Wallace, D. (2004). The influence of architecture in engineering systems. Engineering Systems Monograph, MIT Engineering Systems Division.

Wolfrum, B. (1994). Strategisches Technologiemanagement (2nd ed.). Wiesbaden: Gabler.

Zhang, L. L. (2007). Process platform-based production configuration for mass customization (Doctoral dissertation).

Zott, C., Amit, R., \& Massa, L. (2011). The business model: Recent developments and future research. Journal of Management, 37(4), 1019-1042. http://dx.doi.org/10.1177/0149206311406265

Zwicky, F. (1989). Entdecken, Erfinden, Forschen im morphologischen Weltbild: Mit Diagrammen. In Fritz-Zwicky-Stiftung. Glarus: Baeschlin.

\section{Copyrights}

Copyright for this article is retained by the author(s), with first publication rights granted to the journal.

This is an open-access article distributed under the terms and conditions of the Creative Commons Attribution license (http://creativecommons.org/licenses/by/3.0/). 